\title{
Knowledge and Understanding of Mental Disorders in Families of People with Mental Disorders
}

\author{
Rosalina Sandi ${ }^{1 *}$, Sudirman Nasir ${ }^{1}$, Apik Indarty Moedjiono ${ }^{2}$, Erniwati Ibrahim $^{3}$ \\ ${ }^{1}$ Department of Health Promotion and Behavioral Sciences, Faculty of Public Health, Hasanuddin University, Makassar, \\ Indonesia; ${ }^{2}$ Department of Reproduction Health, Faculty of Public Health, Hasanuddin University, Makassar, Indonesia; \\ ${ }^{3}$ Department of Environmental Health, Faculty of Public Health, Hasanuddin University, Makassar, Indonesia
}

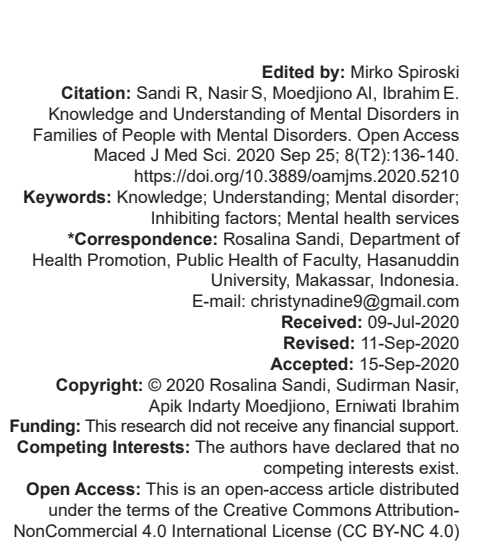

\begin{abstract}
BACKGROUND: Utilization barriers of mental health services are the lack of knowledge about mental health

AIM: This study aimed to identify the knowledge and understanding of the families of people with mental disorders about mental disorders.

METHODS: This study is a qualitative research with phenomenological approach. Data were obtained by interview unstructured observation, and documentation on seven informants in Puskesmas Larompong Luwu, South Sulawesi. Content analysis was used to identify topics or categories in the data.

RESULTS: The family of people with mental disorders still has negative views about people with mental disorders. People with mental disorders are often called the term "lunatic," insane, scary, and dangerous. In addition, people with mental disorders regarded as a person who has a disease that makes people uncomfortable because of behavior that is unnatural. Families have an understanding that the causes of mental disorders associated with the occult and mystical or supernatural events. The factors that cause families have minimal understanding of the appropriate handling for people with mental disorders.

CONCLUSION: It was concluded that the knowledge and understanding of mental disorder which is owned by the family of people with mental disorders as the holder of a healing role in supporting people with mental disorders are lacking.
\end{abstract}

\section{Introduction}

Mental health is one of the targets contained in the Sustainable Development Goals, but often overlooked [1], [2]. In fact, mental health is a fundamental component of the definition of health, which is no less important than physical health [3], [4]. Mental disorders consist of a various problems, with various symptoms, but are generally characterized by some abnormal combinations of thoughts, emotions, behavior, and relationships with others [5]. In the context of mental health, there are two terms for individuals who have mental disorders people with psychiatric problems and the mentally ill [6].

Each individual people with psychiatric problems potentially have mental disorders or psychosocial disabilities [7]. Categories of mental disorders assessed in the 2018 Basic Health Research Data known to consist of mental emotional disorder (anxiety and depression) and severe mental disorders (psychoses) include schizophrenia. Other forms of mental disorder are postpartum depression, dementia, and suicide [8].

Anxiety disorders and depression are one of the most common mental health problems in society [9]. Until now, people with severe mental disorders in Indonesia are still deprived and mistreatment.

The proportion of households that had put in a family member with severe mental disorders was $31.5 \%$ [10]. Although the government has banned the stocks since 1977, Indonesia is even free from stocks for patients with mental disorders is a priority program that must be achieved by the government in 2019 [11], [12]. Some research suggests that barriers on mental health services are knowledge about mental health is lacking [13], [14], [15], [16], [17]. Society generally identifies people who have psychiatric problems with a "madman," because the symptoms are considered strange and different from normal people, while other mental disorders such as depression, anxiety, and mental disorders that appear in various physical complaints are still poorly known [18].

People with mental disorders will come to primary healthcare because of physical complaints. While untrained health workers often focus only on physical complaints by carrying out various checks and providing drugs to overcome them so that their mental problems are often ignored and treatments becomes ineffective [18], [19]. 
Based on preliminary studies carried out in the primary health service in Luwu District, South Sulawesi Province in 2018 stated of 353,277 inhabitants there were $470(0.13 \%)$ recorded cases of mental illness including old cases and new cases, mostly a nuisance cases of schizophrenia and psychotic disorders other chronic of these 252 people (53.6\%) with psychiatric disorders who come to the health center for treatment.

The highest number of visits was in the Larompong health center, 32 people $(78 \%)$ came and were recorded at the health center from 41 cases $(0.19 \%)$ of mental illness. Based on data from the Larompong Health Center, the number of people with mental disorders who visited the Larompong Health Center was increased from the previous year. This is because in Larompong Health Center already have a policy of the health center in an effort to deal with the situation.

Larompong Health Center is a health center that provides mental health services and to this day is currently running well. Therefore, this study aims to identify the knowledge and understanding of the families of people with mental disorders about mental disorders.

\section{Materials and Methods}

This research was conducted at the Larompong Health Center Luwu District, South Sulawesi. This type of research is qualitative research with phenomenological approach. Informants in this study were selected by purposive sampling. The informant in this study was people with mental disorders and family of people with mental disorders.

Data collection methods used in this research is in-depth interviews, unstructured observation and document study. Data analysis used in this study is content analysis which is a way to find the meaning of written or visual material by way of systematic content allocation to the detailed categories by simply dividing the data into small parts and then collecting coding in similar and calculated groups.

\section{Results}

Until now, the handling of families of people with mental disorders has not been satisfactory. The reason is the ignorance of family-related knowledge about the problem of mental disorders. Whereas, on the other hand, the family has a duty to make decisions appropriate health measures for family members sick with implications for the unfair treatment received by people with mental disorders.
The lack of knowledge and understanding of mental disorders cause sufferers often get unpleasant treatment of community family even patients themselves. The treatments were made by people with mental disorders such as discrimination, isolation, ostracism, and even up stocks. The family even considered a mental disorder is a disgrace that they hide the state of the mental disorder of society.

\section{disorders \\ Negative views about people with mental}

People with mental disorders are often seen layman as a strange thing and they casually labeled "lunatic" on people with mental disorders. Besides labeled "lunatic," sequestered away from the people they love, people with mental disorders are also often subjected to inhuman treatment.

The views informant against people with mental disorders is generally negative. Some informants revealed that people suffering from mental disorders are a "madman" and insanity. ODGJ also considered frequent tantrums and carrying weapons so that they feel fear when meeting with ODGJ. The following statement of the informant:

"Crazy people, usually likes to get angry and raged. When I see them on the street, I'm afraid" (MT, 31 Years, Family ODGJ)

"What often carry machetes, do not wear clothes like wandering, just insane"

(MB, 60 Years, Family ODGJ)

Another informant expressed his views that people with mental disorders was dangerous, could hurt themselves and others.

"The disease makes people lose their minds to do a behavior that can be dangerous. If there are things that make him angry, can run amok and to carry a machete, it could hurt themselves and others"

(SM, 41 Years, Family ODGJ)

Not much different views expressed by other informants that ODGJ is a person who has a disease that makes people uncomfortable because of complaints that do unnatural behavior.

"Love alone, when talking with dirty language, his clothes in tatters even do not wear clothes, like collecting used plastic. The interface is not maintained even lazy bath"

(HJ, 56 Years, Family ODGJ)

\section{No proper understanding of the causes of mental disorders}

ODGJ alienating attitude because there is a stigma that the "madness" they caused their belief that these conditions occur because possessed by a demon, 
or because of the sins committed parents, or because ever immoral practices. The existence of this poor outlook, the family that owns ODGJ tends to feel ashamed and try to hide ODGJ of interaction with others. Especially when it happens in families who live in remote areas with low education levels, stocks ended up being the final solution when the shaman or healer could not change the situation.

Interviews showed some informants have an understanding that the causes of mental disorders associated with the occult and mystical or supernatural events. As the informant the following statement:

"If older people antiquity said that he received the knowledge of the ancestors to be able to treat other people. But he was unable to accept the science"

(LH, 52 Years, Family ODGJ)

"It seems as there are female friend who sent witchcraft so that my sister sick like that" (SM, 41 Years, Family ODGJ)

Another informant said that the expression of mental disorders occurs because there are vows of parents who are not satisfied. The following statement of the informant:

"He and his brother suffered from such diseases. Usually, the symptoms will appear when they go wandering, crossing oceans. It seems her parents have first-nazar nazar which is not implemented, so that children suffering from this disease"

(HJ, 56 Years, Family ODGJ)

\section{Minimum understanding regarding proper handling for people with mental disorders}

Disturbingly, due to lack of knowledge about mental disorder so as to cope with mental disorders are usually taken for treatment to a shaman, healer, or even religious leaders to pray for. The results of interviews conducted is known that when experiencing symptoms of psychosis brought some people with mental disorders go to traditional healers, teachers, and the treatment of the supernatural.

"Time began to frequent tantrums, I take to go to traditional healers, but he says this is not a cure. After that I bring to Ustadz for rukiyah but he says this is not a cure"

(LH, 52 Years, Family ODGJ)

"Once I brought to the treatment of the supernatural as I think he's like that because of witchcraft"

(SM, 41 Years, Family ODGJ)

"Delivered treatment to some Ustadz, in rukiyah, but not cured"

(MT, 31 Years, Family ODGJ)

Lack of knowledge about family psychiatric disorder led to a lack of understanding about the family of the symptoms of mental disorders. Families cannot distinguish the symptoms of mental disorders with physical symptoms that are similar. This led to the treatment of people with mental disorders are not exactly the case.

A person with a mental disorder has symptoms start showing symptoms of epilepsy. ODGJ often suffer from seizures that families consider as epilepsy, this causes the patient does not get proper treatment.

"Went to the doctor practice, a neurologist. The clerk at the health center told me he had to go to specialists life, my child epilepsy is not crazy. To what doctor to the soul?"

(MB, 60 Years, Family ODGJ)

\section{Discussion}

These results indicate that the lack of knowledge about mental disorder causing the patient and the family does not know and does not realize that he suffered a mental disorder. Lack of knowledge about mental disorders are caused by the lack of information received by people with mental disorders and family. This ignorance became dominant enough strength inhibitors that affect people with mental disorders that do not utilize mental health services in health centers.

One's knowledge will determine how they behave, as mentioned by Bloom in Notoatmojo (2007) knowledge is sensed or results to know a person against an object. Knowledge is most closely associated with the behavior.

Knowledge is the impression of the human mind as a result of the five senses. Knowledge about health is very important before health actions take place, but the health action may not occur if someone gains knowledge in advance [20]. In the use of health services, a person's behavior is influenced by the form of knowledge.

A person tends to be no use of healthcare services due to the trust and confidence that health services cannot cure the disease, and vice versa [21], [22]. Knowledge of mental health can affect people's behavior in the utilization of mental health services in health centers. Knowledge is very important role because with the knowledge society will be formed stance, will be followed by action selecting a good health service [23].

The results are consistent with research conducted by Brown [14] and Ali [16] which revealed that knowledge of poor mental health is one of the barriers for people with mental disorders to access mental healthcare. The level of knowledge about mental health is known as mental health literacy is defined as the knowledge and understanding of mental disorders to identify, manage, and prevent it. 
A person may seek treatment for themselves or another person optimally. The important thing was first required is able to recognize the symptoms of the disease, determine the cause, knowing the type of treatment, and knowing where medical facilities capable of providing no exception to the treatment of mental disorders [24].

These results indicate that the outlook for people living with mental disorders is generally negative. Some informants still refer to people with mental disorders as "lunatics," insane, scary, and dangerous. While other views provide a definition of people with mental disorders as people who have a disease that makes people uncomfortable because of complaints that do unnatural behavior.

These conditions explain that there are still some families who gave a negative stigma to provide special labels. People with mental disorders are still regarded as an embarrassment or a disgrace to the family or relatives of a family member experiencing a mental disorder to deserve excommunication.

The lack of knowledge about mental disorders make judgments given to people with mental disorders that they are different people with physical illness that can be cured so that labeled as "strange." This has led to the treatment and the wrong attitude toward people with mental disorders.

In contrast to physical health problems (body), which are easily recognizable by the public, the introduction of mental disorders more difficult to grasp. Besides, because of its abstract as well as still very much in terms of mental health is not known. Knowledge of mental health in the community is often overlooked [23].

There are several issues related to the lack of knowledge that the family is usually too late to recognize the early symptoms of the mental disorder. The family will do the search for drugs when the patient has begun to disrupt the activities of the family or the people around him. Some people believe that mental disorders are the result of bad choices.

In studies, Wardhani [25] and Colucci [26] stated that mental disorders occur due to supernatural causes and some are believed due to the offspring of parents or close relatives. The results are consistent with the previous studies that found that the emergence of health problems with symptoms that abstract regarded as something beyond reason (irrational). Everything that is outside of reason in society is regarded as a related to the occult and mystical or supernatural events.

This factor is the main driving force for families to seek treatment efforts using traditional medicine and go to traditional healers, Ustadz or supernatural treatment because it is considered the problem is not a doctor working area [27]. When families do not have enough knowledge about the pain experienced by the patient, they will be looking for information about a place that can cure patients to others [18], [19], [28].
Less familiar terms in mental disorders allows health workers cannot or misidentified their mental disorders in patients. Family cannot tell any complaints or symptoms are in good health providers. Family role in helping the diagnosis is very important because often patients themselves cannot recognize complaints of the [28].

Lack of understanding of the family will be the early symptoms because the family cannot distinguish the symptoms of mental disorders with symptoms of other physical ailments. Besides the lack of good communication between doctor and patient family related health symptoms of the disease makes improper handling occur [29], [30].

This study found that the people with mental disorders who have symptoms start showing symptoms of epilepsy, the seizures so frequently misdiagnosed as epilepsy. In the next development for handling initial treatment for the disease is not maximal, exacerbating the psychological condition of the patient.

People with mental disorders may not be able to overcome their own mental problems. Tesebut individual takes the role of other people around, especially families. Knowledge and information about mental disorders should be known by the whole of society, ranging from the causes of mental disorder to determine the appropriate treatment for them to be able to recover.

\section{Recommendation}

Knowledge and understanding of mental disorder which is owned by the family of people with mental disorders as caregiver who plays a role in supporting the healing of patients are still lacking. Family outlook generally still refer people with mental disorders as "lunatics," insane, scary, and dangerous.

Families also understand that mental disorders result from the occult and mystical or supernatural events. These factors encourage the family to seek treatment efforts using traditional medicine, religious leaders, or the treatment of the supernatural. Public health center and health workers advised to improve the provision of information and health education through counseling and mental health promotion to family of people with mental disorders and community programmed to improve mental health services.

\section{References}

1. Votruba N, Eaton J, Prince M, Thornicroft G. The importance of global mental health for the sustainable development goals. J Mental Health. 2014;23(6):283-6. https://doi.org/10.3109/09638 237.2014.976857 
2. Izutsu T, Tsutsumi A, Minas $H$, Thornicroft $G$, Patel V, Ito A. Mental health and wellbeing in the sustainable development goals. Lancet Psychiatry. 2015;2(12):1052-4. https://doi. org/10.1016/s2215-0366(15)00457-5

\section{PMid:26613844}

3. Idaiani S. Kesehatan jiwa di Indonesia dari deinstitusionalisasi sampai desentralisasi. J Kesehatan Masyarakat Nasional. 2010;4(5):203-209. https://doi.org/10.21109/kesmas.v4i5.170

4. Ohrnberger J, Fichera E, Sutton M. The relationship between physical and mental health: A mediation analysis. Soc Sci Med. 2017;195(17):42-9. https://doi.org/10.1016/j. socscimed.2017.11.008

PMid:29132081

5. World Health Organization. Factsheet on Mental Disorders. Geneva: World Health Organization; 2017.

6. Republik Indonesia. Undang-undang Nomor 18 Tahun 2014 Tentang Kesehatan Jiwa. Jakarta: Republik Indonesia; 2014. https://doi.org/10.31219/osf.io/pmwny

7. Yazfinedi Y. Konsep, permasalahan dan solusi penyandang disabilitas mental di Indonesia. Quantum. 2018;14(26):101-110.

8. World Health Organization. Global Mental Health 2015. Geneva: World Health Organization; 2015.

9. Kelleher I, Devlin N, Wigman JT, Kehoe A, Murtagh A, Fitzpatrick $\mathrm{C}$, et al. Psychotic experiences in a mental health clinic sample: Implications for suicidality, multimorbidity and functioning. Psychol Med. 2014;44(8):1615-24. https://doi. org/10.1017/s0033291713002122 PMid:24025687

10. Kemenkes RI. Badan Penelitian dan Pengembangan Kesehatan, Laporan Riset Kesehatan Dasar 2018. Jakarta: Kementerian Kesehatan Republik Indonesia; 2018. https://doi. org/10.6066/jtip.2013.24.2.121

11. Sharma K. Living in Hell: Abuses Againts People with Psichosocial Disabilities in Indonesia. New York: Human Right Watch; 2016.

12. Yusuf A, Tristiana DR. Fenomena pasung dan dukungan keluarga terhadap pasien gangguan jiwa pasca pasung. J Keperawatan Padjadjaran. 2018;5(3):302-14. https://doi. org/10.24198/jkp.v5i3.653

13. Langley AK, Nadeem E, Kataok SH, Stein BD, Jaycox LH. Evidence-based mental health programs in schools: Barriers and facilitators of successful implementation. School Ment Health. 2010;2(3):105-13. https://doi.org/10.1007/s12310-010-9038-1 PMid:20694034

14. Brown A, Rice SM, Rickwood DJ, Parker AG. Systematic review of barriers and facilitators to accessing and engaging with mental health care among at-risk young people. Asia Pac Psychiatry. 2016;8(1):3-22. https://doi.org/10.1111/appy.12199 PMid:26238088

15. Ross LE, Vigot S, Wishard J, Waese M, Spence JD, Oliver J, et al. Barriers and facilitators to primary care for people with mental health and/or substance use issues: A qualitative study. BMC Fam Pract. 2015;16(1):135-48. https://doi.org/10.1186/ s12875-015-0353-3 PMid:26463083

16. Ali K, Farrer L, Fassnacht DB, Gulliver A, Bauer S, Griffiths KM. Perceived barriers and facilitators towards help-seeking for eating disorders: A systematic review. Int $\mathrm{J}$ Eat Disord. 2017;50(1):9-2. https://doi.org/10.1002/eat.22598 PMid:27526643

17. Rahayuni IG, Darsana IW, Adianta IK, Wicaksana AA,
Wulandari IA. Pemanfaatan pelayanankesehatan jiwa di Puskesmas oleh keluarga penderita skizofrenia di Provinsi Bali. J Riset Kesehatan Nasional. 2018;1(1):76-81. https://doi. org/10.37294/jrkn.v1i1.33

18. Andersson LM, Schierenbeck I, Strumpher J, Krantz G Topper K, Backman G, et al. Help-seeking behaviour, barriers to care and experience of care among persons with depression in Eastern Cape, South Africa. J Affect Disord. 2013;151(2):43948. https://doi.org/10.1016/j.jad.2013.06.022 PMid:23890669

19. Sun KS, Lam TP, Lam KF, Lo TL, Chao DV, Lam EW. Barriers of Chinese primary care attenders to seeking help for psichological distress in Hong Kong. J Affect Disord. 2016;196(20):164-70. https://doi.org/10.1016/j.jad.2016.02.041 PMid:26922145

20. Notoatmodjo S. Promosi Kesehatan dan IImu Perilaku. Jakarta: Rineka Cipta; 2007.

21. Rickwood D, Deane FP, Wilson CJ, Ciarrochi J. Young people's help seeking for mental health problems. Aust E J Adv Ment Health. 2005;4(3):218-51. https://doi.org/10.5172/jamh.4.3.218

22. Mak HW, Davis JM. The application of the theory of planned behavior to help seeking intention in a Chinese society. Soc Psychiatry Psychiatr Epidemiol. 2013;49(9):1501-15. https://doi. org/10.1007/s00127-013-0792-x PMid:24233100

23. Jorm AF. Mental health literacy, public knowledge and beliefs about mental disorders. Br J Psychiatry. 2000;177(5):396-401. https://doi.org/10.1192/bjp.177.5.396 PMid:11059991

24. Jorm AF, Korten AE, Jacomb PA, Christensen H, Rodgers B, Pollitt P. Mental health literacy: A survey of the public's ability to recognize mental disorders and their beliefs about the effectiveness of treatment. Med J Aust. 1997;166(4):182-6. https://doi.org/10.5694/j.1326-5377.1997.tb140071.x PMid:9066546

25. Wardhni IY. Dukungan keluarga: Faktor penyebab ketidakpatuhan klien skizofrenia menjalani pengobatan. J Keperawatan Indones. 2012;15(1):1-6. https://doi.org/10.7454/ jki.v15i1.40

26. Colucci E, Minas H, Szwarc J, Guerra C, Paxton G. In or out? Barriers and facilitators to refugee-background young people accessing mental health services. Transcult Psychiatry. 2015;52(6):766-90. https://doi.org/10.1177/1363461515571624 PMid:25731986

27. Burns JK. The burden of untreated mental disorders in KwaZulu-Natal Province-mapping the treatment gap. South Afr J Psychiatry. 2014;20(1):6-10. https://doi.org/10.4102/ sajpsychiatry.v20i1.499

28. Umubyeyi A, Mogren I, Ntaganira J, Krantz G. Help-seeking behaviours, barriers to care and self-efficacy for seeking mental health care: Population-based study in Rwanda. Social Psychiatry Psychiatr Epidemiol. 2016;51(1):81-92. https://doi. org/10.1007/s00127-015-1130-2 PMid:26433379

29. Putri AS, Martiningtyas MA, Sagala AE, Erawan GN, Yana IP, Martiningtyas D. Era baru kesehatan mental Indonesia: Sebuah kisah dari desa siaga sehat jiwa (DSSJ). J Psikol. 2013;40(2):169-180. https://doi.org/10.36418/syntax-literate. v5i4.1082

30. Rosdiana R. Identifikasi peran keluarga penderita dalam upaya penanganan gangguan jiwa skizoprenia. J MKMI. 2018;14(2):174-80. https://doi.org/10.30597/mkmi.v14i2.3787 